\title{
A Natural Fermented Food as a Possible Cause of Syndrome of Inappropriate Secretion of Antidiuretic Hormone
}

\author{
Hidetaka Hamasaki
}

\begin{abstract}
Syndrome of inappropriate secretion of antidiuretic hormone (SI$\mathrm{ADH})$ is caused by various drugs used in routine medical practice. Manda $\operatorname{Koso}^{\circledR}(\mathrm{MK})$ is a fermented food product that contains many natural materials. Since MK is a natural food, it is considered to have no significant adverse effects. However, here we report a case of SIADH suspected of being induced by MK. A 76-year-old woman presenting with headache and vomiting was admitted. Blood examination revealed severe hyponatremia, with a serum sodium level of 120 $\mathrm{mEq} / \mathrm{L}$. Based on the results of careful examination, the diagnosis was SIADH. She had no history of central nervous system disorder or lung disease, and therefore drug-induced SIADH was considered. MK was a suspected product. One month after stopping taking MK, her symptoms disappeared, and serum sodium level, urinary sodium excretion, plasma and urinary osmolality, and plasma ADH level had completely normalized. Clinicians should be noted that a natural fermented food product can induce SIADH.
\end{abstract}

Keywords: SIADH; Natural fermented food; Ginger

\section{Introduction}

Syndrome of inappropriate secretion of antidiuretic hormone (SIADH), the most common cause of euvolemic hyponatremia, is characterized by hyponatremia without dehydration or overhydration, excessive urinary sodium excretion, and hypertonicity of urine [1]. SIADH is caused by central nervous system disease, including meningitis, cerebral infarction, and hemorrhage, as well as by lung disease such as pneumonia, bronchial asthma, tuberculosis, and small cell lung cancer [1-3]. In addition, various drugs used in routine medical practice can potentially cause SIADH, including tricyclic antidepressants, carbamazepine, phenothiazine, haloperidol, serotonin uptake inhibitors,

Manuscript accepted for publication November 19, 2015

Department of Internal Medicine, National Center for Global Health and Medicine Kohnodai Hospital, 1-7-1 Kohnodai, Chiba, Japan.

Email: hhamasaki78@gmail.com

doi: http://dx.doi.org/10.14740/jem320w quinolones, cyclophosphamide, chlorpropamide, diuretics, and non-steroidal anti-inflammatory drugs (NSAIDs) [4].

Manda Koso ${ }^{\circledR}$ (Manda Fermentation Co., Ltd, Innoshima, Japan) (MK) is a fermented food product that contains many natural materials, including brown sugar, vegetables, fruits, cereals, and seaweed, that have been fermented and matured together for more than 3 years [5]. Previous studies have shown that $\mathrm{MK}$ has anticancer and antioxidant effects in vivo and in vitro $[6,7]$, and therefore the clinical applicability of $\mathrm{MK}$ has recently started attracting attention. Since MK is a natural food, it is considered to have no significant adverse effects. A case of SIADH suspected of being induced by MK is reported for the first time here.

\section{Case Report}

A 76-year-old woman presented with headache and vomiting in June and was admitted. She had experienced persistent headache since April and had been examined by a neurosurgeon in May. Brain magnetic resonance imaging (MRI) had revealed no specific abnormal findings and she was being followed without treatment. However, her headache persisted and after vomiting twice, she was brought to the emergency room.

Upon admission, she reported that her headache had improved slightly compared with before transfer, but she also showed mild disturbance of consciousness and vomited once again. All vital signs were normal, and no paralysis or paresthesia was observed. Physical examination to assess for meningeal irritation revealed no neck stiffness, jolt accentuation, or Kernig's sign. Similarly, computed tomography of the head and brain MRI showed no abnormal findings such as cerebral hemorrhage, cerebral infarction, or brain tumor. However, blood examination revealed severe hyponatremia, with a serum sodium level of $120 \mathrm{mEq} / \mathrm{L}$. Although thyroid and adrenal cortical function were normal, plasma antidiuretic hormone (ADH) levels were elevated to $4.1 \mathrm{pg} / \mathrm{mL}$. Urinary sodium excretion was markedly increased $(113 \mathrm{mEq} / \mathrm{L})$ and plasma osmolality decreased ( $\left.244 \mathrm{mOsm} / \mathrm{kg} \mathrm{H}_{2} \mathrm{O}\right)$, but urinary osmolality was normal (462 $\mathrm{mOsm} / \mathrm{kg} \mathrm{H}_{2} \mathrm{O}$ ). Based on these results, the diagnosis was SIADH. Hyponatremia was ameliorated by restricting water intake to $1,000-1,500 \mathrm{~mL} /$ day.

With respect to the cause of SIADH, the patient had no history of central nervous system disorder or lung disease, 
Table 1. Changes in Biochemical Data ADH: Antidiuretic Hormone

\begin{tabular}{lll} 
& $\begin{array}{l}\text { On } \\
\text { admission }\end{array}$ & $\begin{array}{l}\text { 1 month after } \\
\text { discharge }\end{array}$ \\
\hline Serum sodium levels $(\mathrm{mEq} / \mathrm{L})$ & 120 & 142 \\
Urinary sodium levels $(\mathrm{mEq} / \mathrm{L})$ & 113 & 36 \\
Plasma osmolality $\left(\mathrm{mOsmol} / \mathrm{kg} \mathrm{H}_{2} \mathrm{O}\right)$ & 244 & 290 \\
Urinary osmolality $\left(\mathrm{mOsmol} / \mathrm{kg} \mathrm{H}_{2} \mathrm{O}\right)$ & 462 & 727 \\
ADH $(\mathrm{pg} / \mathrm{mL})$ & 4.1 & 1.2 \\
\hline
\end{tabular}

and therefore drug-induced SIADH was considered. She had previously taken etizolam and rabeprazole for a few years without adverse reactions and was not currently taking any drugs known to potentially cause SIADH. Careful questioning revealed that she had started taking MK in April to relieve constipation. The patient stopped taking MK during hospitalization and after discharge. Following discharge, she did not restrict her water intake and refrained from taking MK. At 1 month after discharge, serum sodium level, urinary sodium excretion, plasma and urinary osmolality, and plasma ADH level had normalized (Table 1).

\section{Discussion}

The beneficial effects of MK on oxidative stress [7], natural killer cell activity [8], and breast cancer cells [6] have been suggested by previous studies, and no adverse effects of MK in human subjects have been reported to date. The present case is the first report of SIADH suspected of being induced by MK.

Drug-induced SIADH can sometimes be clinically asymptomatic and remain underdiagnosed. Drug-induced hyponatremia can be caused by a variety of drugs and can reach an incidence of $5-14 \%$ [4]. The present patient took a particular formulation of MK different from the standard MK product, namely, Manda Koso plus on ${ }^{\circledR}$ that has added ginger. This suggests that ginger may have been responsible for causing SI$\mathrm{ADH}$ in this patient, and the mechanism could be explained as follows. Ginger suppresses prostaglandin synthesis through the inhibition of cyclooxygenase-1 and cyclooxygenase-2, identical to the pharmacological action of NSAIDs [9]. NSAIDs enhance endogenous $\mathrm{ADH}$ action by blocking prostaglandin synthesis [10], and it is this blocking of prostaglandin synthesis that is thought to be the pathogenic mechanism of NSAIDinduced SIADH. Furthermore, in a randomized control trial, ginger significantly reduced prostaglandin E2 (PGE2) level compared with placebo [11]. PGE2 directly inhibits salt and water absorption [12], and a decreased PGE2 level due to excessive ginger intake could cause SIADH. Investigations should be made to examine whether consuming a natural fermented food product including ginger can induce SIADH and if a dose-response relationship exists between ginger intake and the incidence rate of SIADH.

\section{Competing Interests}

The author declares that he has no competing interests.

\section{References}

1. Peri A, Pirozzi N, Parenti G, Festuccia F, Mene P. Hyponatremia and the syndrome of inappropriate secretion of antidiuretic hormone (SIADH). J Endocrinol Invest. 2010;33(9):671-682.

2. Karaca P, Desailloud R. [Hormonal dysnatremia]. Ann Endocrinol (Paris). 2013;74(Suppl 1):S42-51.

3. Vantyghem MC, Balavoine AS, Wemeau JL, Douillard C. Hyponatremia and antidiuresis syndrome. Ann Endocrinol (Paris). 2011;72(6):500-512.

4. Ramos-Levi AM, Duran Rodriguez-Hervada A, MendezBailon M, Marco-Martinez J. Drug-induced hyponatremia: an updated review. Minerva Endocrinol. 2014;39(1):112.

5. Kawai M, Matsuura S, Mori A. Free radical scavenging action of Manda. Clin Rep. 1993;28:393-397.

6. Marotta F, Yadav H, Pathak S, Minelli E, Signorelli P, Lorenzetti A, Marandola P. Inhibition of human breast cancer cell growth and enzymatic activity by a fermented nutraceutical: an in vitro and in vivo study. Ann N Y Acad Sci. 2009;1155:273-277.

7. Kawai M, Matsuura S, Asanuma M, Ogawa N. Manda, a fermented natural food, suppresses lipid peroxidation in the senescent rat brain. Neurochem Res. 1998;23(4):455461.

8. Yamamoto H, Kiyomatsu K, Hirose N, Sakai D, Katano M. Postoperative effect of Manda on NK cell activity in cancer patients. Biotherapy. 1999;13(7):805-809.

9. Grzanna R, Lindmark L, Frondoza CG. Ginger--an herbal medicinal product with broad anti-inflammatory actions. J Med Food. 2005;8(2):125-132.

10. Culpepper RM, Andreoli TE. Interactions among prostaglandin E2, antidiuretic hormone, and cyclic adenosine monophosphate in modulating $\mathrm{Cl}$ - absorption in single mouse medullary thick ascending limbs of Henle. J Clin Invest. 1983;71(6):1588-1601.

11. Arablou T, Aryaeian N, Valizadeh M, Sharifi F, Hosseini A, Djalali M. The effect of ginger consumption on glycemic status, lipid profile and some inflammatory markers in patients with type 2 diabetes mellitus. Int J Food Sci Nutr. 2014;65(4):515-520.

12. Breyer MD, Breyer RM. Prostaglandin E receptors and the kidney. Am J Physiol Renal Physiol. 2000;279(1):F1223. 